$\mathrm{Nr} 3(66)$, 2020, s. 67-77

https://doi.org/10.12797/Politeja.17.2020.66.04

\author{
Marta LABUDA (D) \\ Uniwersytet Jagielloński \\ marta.labuda@doctoral.uj.edu.pl
}

\title{
KRYZYS UKRAIŃSKI WYZWANIEM \\ DLA ROZWOJU RELACJI GOSPODARCZYCH UKRAINY Z UNIĄ EUROPEJSKĄ
}

ABSTRACT The Ukrainian Crisis as a Challenge for Development of Economic Relations between Ukraine and European Union

The present article is an attempt to look at European economic integration in terms of the Ukrainian crisis that not only Ukraine, but the entire area of Eastern Europe and the European Union must deal with. The purpose of the research is to demonstrate the impact of the Ukrainian crisis on economic integration of Ukraine with the EU. The research has been based on a mixed methodology due to the interdisciplinary subject of the article. The sequential exploratory strategy has been used. The research proves the Ukrainian crisis contributes to the trade exchange instability and causes disruptions in capital cooperation between the EU and Ukraine. The serious crisis shows how important a solid policy is to integrate this country with the EU.

Keywords: Ukrainian crisis, European economic integration, Ukraine, European Union, deep and comprehensive free trade area

Słowa kluczowe: kryzys ukraiński, europejska integracja gospodarcza, Ukraina, Unia Europejska, pogłębiona i kompleksowa strefa wolnego handlu 


\section{UWAGI WSTĘPNE}

Ukraina od samego początku swojej niezależności deklarowała zbliżenie z Unią Europejską (UE). Mimo iż integracja Ukrainy z UE trwa już ponad 28 lat, współpraca ta w dalszym ciągu mierzy się z wieloma trudnościami.

Partnerstwo Wschodnie (inicjatywa unijna mająca na celu zacieśnienie relacji z państwami Europy Wschodniej i Zakaukazia) już od momentu powstania zetknęło się z negatywnym podejściem Rosji. Początkowo Kreml ograniczał się do regularnej krytyki politycznej. Z kolei przybliżająca się perspektywa podpisania przez UE pierwszych czterech umów o stowarzyszeniu z państwami Partnerstwa Wschodniego, w tym z Ukrainą, która została uznana przez Rosję za zmianę geopolitycznego układu sił w Europie i bezpośrednie zagrożenie dla rosyjskich konstrukcji geopolitycznych (takich jak „russkij mir”, Unia Euroazjatycka), spowodowała zmasowaną presję Rosji (restrykcje handlowe, zachęty finansowe, bezpośrednie naciski polityczne) wobec Ukrainy w lipcu 2013 r. ${ }^{1}$

Zapowiedź prezydenta Ukrainy Wiktora Janukowycza, że na szczycie Partnerstwa Wschodniego w Wilnie (29 listopada 2013 r.) nie podpisze umowy stowarzyszeniowej z UE, była szeroko komentowana w środkach masowego przekazu jako porażka polityki Zachodu i otwarcie drogi do reintegracji Ukrainy z Rosją ${ }^{2}$. Odmowa podpisania danej umowy wywołała masowe protesty ze strony zwolenników stowarzyszenia. Protesty (zwane Euromajdanem) doprowadziły ostatecznie do rewolucji, która obaliła rządy Janukowycza, a następnie do niepokojów na głównie rosyjskojęzycznym wschodzie i południu kraju. Kryzys polityczny nasilił się jeszcze po interwencji wojsk rosyjskich we wschodnich regionach i aneksji Krymu. W wyniku umocnienia przez rosyjską inwazję buntowniczych nastrojów wśród rosyjskojęzycznych Ukraińców, zamieszki w Doniecku i Ługańsku przerodziły się ostatecznie w wojnę przeciwko porewolucyjnemu rządowi Ukrainy i powstanie separatystyczne, niejednokrotnie wspierane przez wojsko i siły specjalne Federacji Rosyjskiej. Wydarzenia te spowodowały, że Ukraina znalazła się w stanie poważnego kryzysu, który z biegiem czasu przybrał oblicze ustrojowe, polityczne, gospodarcze, etniczne i społeczne, w efekcie doprowadzając do konfliktu militarnego z Federacją Rosyjską ${ }^{3}$.

Ostatecznie nowa władza podpisała polityczną część umowy stowarzyszeniowej z UE dotyczącą handlu 21 marca 2014 r. Z kolei 27 czerwca tegoż roku podpisano drugą jej część. Większa część układu jest stosowana od 2014 r., a 1 stycznia 2016 r. weszła w życie umowa o pogłębionej i kompleksowej strefie wolnego handlu $\left(\right.$ DCFTA $\left.^{4}\right)$,

J. Truszczyński, Partnerstwo Wschodnie - geneza i wstępny bilans, [w:] Partnerstwo Wschodnie Unii Europejskiej, red. M. Grela, Z. Rapacki, Warszawa 2016, s. 21.

2 S. Olszyk, Kontekst geopolityczny kryzysu na Ukrainie (2013-2014) i zaangażowanie wtadz polskich w jego rozwiązanie, „Środkowoeuropejskie Studia Polityczne” 2016, nr 3, s. 268, [online] http://ssp.amu.edu. pl/wp-content/uploads/2017/03/ssp-2016-3-12.pdf, doi 10.14746/ssp.2016.3.12, 3 XII 2019.

3 Tamize, s. 267.

4 DCFTA - Deep and Comprehensive Free Trade Area. 
będąca najważniejszą i największą częścią umowy stowarzyszeniowej między Ukrainą a UE. Decyzję o zawarciu całości układu przyjęto 11 lipca 2017 r., co było ostatnim krokiem w procesie ratyfikacji. Pozwolił on na jego stosowanie od 1 września 2017 r. ${ }^{5}$

Główne pytanie badawcze postawione w niniejszym artykule brzmi: jak kryzys ukraiński wpływa na relacje gospodarcze Ukrainy z UE? W odpowiedzi na pytanie badawcze przyjęto główną hipotezę badawczą. Jest nią stwierdzenie, iż kryzys ukraiński spowodował spadek wymiany handlowej oraz pogorszenie się wyników współpracy kapitałowej pomiędzy UE a Ukrainą.

\section{ISTOTA I ZAKRES DCFTA}

Europejska integracja gospodarcza opiera się na założeniu, że wolny handel oraz otwarcie rynku na współpracę z innymi krajami i regionami ma pozytywny wpływ na wzrost gospodarczy, a także tworzenie nowych miejsc pracy. Co więcej, proces otwarcia europejskiego rynku w ostatnich latach znacząco przybrał na sile ${ }^{6}$.

UE jest największą na świecie potęgą handlową, która posiada lub negocjuje umowy handlowe z praktycznie wszystkimi znaczącymi gospodarkami świata ${ }^{7}$. Na koniec 2019 r. obowiązywało około 40 umów handlowych wiążących UE z państwami trzecimi, a jedną z nich była umowa z Ukrainą.

DCFTA, gospodarcza część umowy stowarzyszeniowej pomiędzy Ukrainą a UE, weszła w życie 1 stycznia $2016 \mathrm{r}^{8}{ }^{8}$ Wówczas umowę określono jako jedną z najbardziej ambitnych umów bilateralnych. Liczyła ona 15 rozdziałów, 14 załączników oraz 3 protokoly9.

Podpisana umowa przewidywała nie tylko powołanie strefy wolnego handlu, a także przyjęcie przez Ukrainę około $60 \%$ unijnego prawa, w tym regulacji w zakresie energii, przepisów technicznych, sanitarnych, fitosanitarnych, celnych czy dotyczących

M. Labuda, Realizacja Partnerstwa Wschodniego przez Ukraine, „Kurier Galicyjski” 2018, nr 13 (305), s. 13.

6 B. Płonka, Umowa UE-Ukraina o utworzeniu pogtębionej i kompleksowej strefy wolnego handlu (DCFTA) jako przyktad nowej generacji porozumień preferencyjnych, „Zeszyt Naukowy Wyższej Szkoły Zarządzania i Bankowości w Krakowie” 2015, nr 38, s. 44, [online] http://cejsh.icm.edu.pl/cejsh/ element/bwmeta1.element.desklight-37e7a265-a232-42ea-8537-f87f912d8190/c/plonka.pdf, 3 XII 2019.

7 H. Luczkiewicz, Czy umowy handlowe zawierane przez UE przynosza realne korzyści?, 21 III 2019, https://www.wnp.pl/rynki-zagraniczne/czy-umowy-handlowe-zawierane-przez-ue-przynosza-realne-korzysci,342256.html, 4 XII 2019.

$8 \quad$ Ukraina bierze się za handel $z$ Unia. W życie wchodzi DCFTA, TVN 24 BIS, 1 I 2016, [online] https://tvn24bis.pl/ze-swiata,75/1-stycznia-wchodzi-w-zycie-dcfta-umowa-o-wolnym-handlu-z-ukraina,607341.html, 5 XII 2019.

9 E. Radomska, DCFTA - umowa o strefie wolnego handlu Ukrainy z Unia Europejska - szanse, zagrożenia, wyzwanie, „Kwartalnik Naukowy Uczelni Vistula” 2017, nr 2 (55), s. 63, [online] http://cejsh.icm. edu.pl/cejsh/element/bwmeta1.element.desklight-ad85d97f-88e3-4dee-9bf6-a6778beda041/c/04_ PDFsam_KNUV_52_poprawiony.pdf, 5 XII 2019. 
ochrony własności intelektualnej. Miała ona zabezpieczyć przepływ kapitału oraz utworzyć równe warunki konkurencji ${ }^{10}$. Umowa przewidywała zniesienie większości opłat celnych zarówno w imporcie, jak i eksporcie, oraz stosowanie instrumentów ochrony handlu - ukraińskie i unijne przedsiębiorstwa, produkty, usługi i instytucje miały być traktowane w taki sam sposób. Umowa zakładała stopniowe dostosowanie ukraińskich regulacji technicznych i standardów do tych obowiązujących w UE, dostosowanie ukraińskiego prawodawstwa w zakresie standardów sanitarnych i fitosanitarnych do prawodawstwa UE oraz powołanie podkomitetu monitorującego wdrażanie prawa zgodnie z zapisami protokołów DCFTA oraz norm Światowej Organizacji Handlu (WTO $)^{11}$. Umowa miała przyczynić się do wzmocnienia współpracy celnej pomiędzy stronami oraz uproszczenia procedur celnych w celu wzmocnienia dwustronnej wymiany gospodarczej w oparciu o zasadę niedyskryminacji. Dzięki niej Ukraina winna uzyskać dostęp do rynku wewnętrznego UE, a szczególnie do rynku usług. Strony zobowiązały się również zapewnić niczym nieograniczony przepływ kapitału i inwestycji ${ }^{12}$. Umowa o wolnym handlu zakładała całkowitą integrację Ukrainy z unijnym rynkiem zamówień publicznych, ochronę prawa do własności intelektualnej, zakaz stosowania praktyk mających na celu utrudnianie lub ograniczanie konkurencji, nadużywania pozycji dominującej przez przedsiębiorstwa oraz prowadzenia działań dążących do monopolizacji rynku lub znacznego ograniczenia konkurencji na terytorium zarówno UE, jak i Ukrainy. Zakładano również współpracę w dziedzinie energii. Umowa wyrażała także potrzebę promowania zasad zrównoważonego rozwoju w ramach wymiany handlowej pomiędzy Ukrainą a UE oraz wprowadzała mechanizm rozstrzygania sporów bazujący na istniejących instrumentach w ramach $\mathrm{WTO}^{13}$.

DCFTA zapewniała Ukrainie dość długie okresy przejściowe w wielu obszarach, co umożliwić miało stopniową zmianę regulacji prawnych. Przeniesienie ich do ukraińskiego systemu prawnego wymagało przyjęcia przez Radę Najwyższą tego państwa odpowiednich ustaw, zgodnie z planem nakreślonym w aneksach do porozumienia ${ }^{14}$.

\section{CHARAKTERYSTYKA WYMIANY HANDLOWEJ UE-UKRAINA}

Handel zagraniczny był jednym z pierwszych obszarów, w którym państwa członkowskie zdecydowały połączyć swoje siły. UE wspiera otwarty i uczciwy system handlu międzynarodowego. Niezłomnie pracuje ona nad zapewnieniem integracji wszystkich

101 stycznia wchodzi w życie DCFTA - umowa o wolnym handlu z Ukraina, Polska Agencja Prasowa, 1 I 2016, [online] https://www.pap.pl/aktualnosci/news\%2C452052\%2C1-stycznia-wchodzi-w-zycie-dcfta---umowa-o-wolnym-handlu-z-ukraina.html, 6 XII 2019.

11 Uktad o stowarzyszeniu między Unia Europejska i jej państwami cztonkowskimi, z jednej strony, a Ukraina, $z$ drugiej strony, Dz. U. UE L 161/3.

12 Tamże.

13 Tamże.

14 E. Radomska, DCFTA..., s. 63. 
krajów w ramach gospodarki światowej, między innymi drogą stopniowego znoszenia ograniczeń w handlu międzynarodowym ${ }^{15}$.

Obraz międzynarodowego handlu towarami pomiędzy UE a Ukrainą w latach 2010-2018 przedstawia znaczną niestałość (wykres 1).

Wykres 1. Eksport, import, bilans handlowy UE-Ukraina w latach 2010-2018 w mld EUR

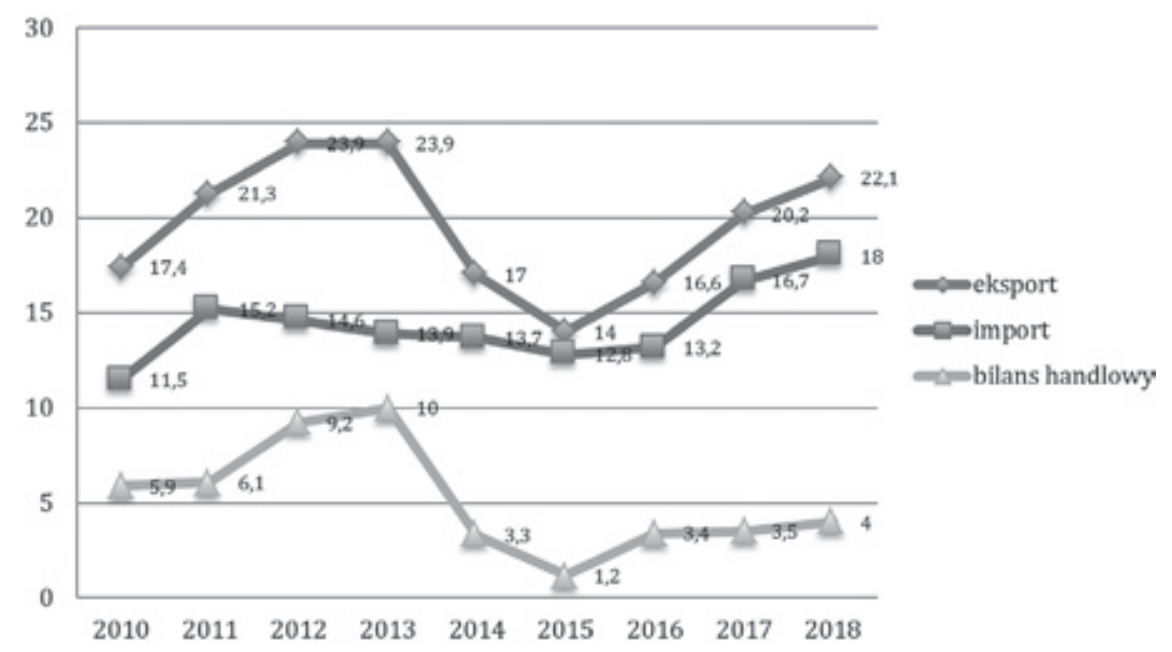

Źródło: Eurostat (online data code: ext_It_maineu).

Analizując wartość eksportu UE na Ukrainę w latach 2010-2018, zaobserwowano znaczne wahania. Po załamaniu się eksportu w 2009 r., którego głównym powodem były skutki globalnego kryzysu finansowego, następował systematyczny wzrost eksportu UE, a następnie spadek. Wartość eksportu wzrastała do 2013 r., po czym gwałtownie spadła w 2014 r., a jeszcze bardziej w 2015 r. Wartość eksportu w 2015 r. była niemalże dwukrotnie mniejsza w porównaniu do $2013 \mathrm{r}$. Z kolei po 2015 r. odnotowano stopniowy wzrost wartości eksportu UE. Powodem tego było podpisanie pozostałych części umowy stowarzyszeniowej Ukrainy z UE, a wraz z tym wejście w życie DCFTA.

Podobne zmiany rozpoznano, analizując wartość importu z Ukrainy. W 2009 r. wartość importu gwałtownie spadła, a po chwili znów wzrosła. Następnie od 2011 r. dochody z importu stabilnie spadały. Wartość importu państw członkowskich UE z Ukrainy zmniejszyła się o $25 \%$. Wynikało to m.in. ze spadku cen na rynkach światowych na produkty, które są najważniejsze w strukturze ukraińskiego eksportu, takie jak żelazo i stal oraz zboża. Wiele ukraińskich przedsiębiorstw zrezygnowało ze sprzedaży produktów do państw UE, np. w związku ze wzrostem kosztów importu towarów niezbędnych do produkcji (m.in. nawozów) ${ }^{16}$. Miejsce tych przedsiębiorstw zajęly

15 Unia Europejska i jejpartnerzy handlowi, Parlament Europejski. Noty tematyczne o Unii Europejskiej, 1 XI 2019, [online] http://www.europarl.europa.eu/ftu/pdf/pl/FTU_5.2.1.pdf, 6 XII 2019.

16 Tamże, s. 67. 
nowe, które dopiero poszukiwały odbiorców. Po 2015 r. zauważono jednak stopniowy wzrost wartości importu, czego powodem było podpisanie pozostałych części umowy stowarzyszeniowej.

Saldo bilansu handlowego w latach 2010-2018 również podlegało znacznym fluktuacjom. Warto przypomnieć, iż w 2008 r. UE odnotowała nadwyżkę handlową z Ukrainą w wysokości prawie 11 mld EUR. Eksport UE na Ukrainę był najwyższy w $2008 \mathrm{r}$. (25 mld EUR), a najniższy w latach 2009 i 2015 (oba 14 mld EUR). Z kolei import UE z Ukrainy był najwyższy w 2018 r. (18 mld EUR), a najniższy w 2009 r. (8 mld EUR). W latach 2008-2018 UE miała dodatni bilans handlowy z Ukrainą. Ta nadwyżka była najwyższa w 2013 r., kiedy osiągnęła 10 mld EUR, a najniższa w 2015 r. - do 1 mld EUR.

Konkludując, wahania w wymianie handlowej pomiędzy UE a Ukrainą w latach 2010-2018 powstawały na różnym tle. Pewnym jest twierdzenie, iż powodem załamania się eksportu i importu w 2009 r. były skutki globalnego kryzysu finansowego. Podobnie możemy argumentować gwałtowny spadek wartości eksportu i importu w 2014 r. Kryzys ukraiński, obejmujący polityczne i militarne zaangażowanie się Federacji Rosyjskiej po stronie ukraińskich separatystów, zyskał wówczas wymiar międzynarodowy ${ }^{17}$. Mimo iż w początkowym okresie buntu demonstranci domagali się zmiany stanowiska władz i podpisania umowy stowarzyszeniowej, to z czasem manifestacje przerodziły się w okupację centralnego placu w stolicy, tzw. Majdanu Niepodległości (Euromajdanu) ${ }^{18}$. Konflikt pomiędzy władzą a obywatelami w konsekwencji doprowadził do obalenia głowy państwa w wyniku pozakonstytucyjnego przewrotu państwowego. Ponadto stanowił on katalizator rozpadu państwa i rosyjskiej interwencji w obronie separatystów na Wschodzie i Krymie ${ }^{19}$. Zgodnie z powyższym pewnym jest twierdzenie, iż wybuch kryzysu ukraińskiego zdecydowanie pogorszył stan bilansu handlowego pomiędzy UE a Ukrainą w 2014 r. Dodatkowo eskalacja kryzysu ukraińskiego doprowadziła do większego spadku wyników bilansu handlowego rok później. Korzystnym było podpisanie pozostałych części umowy stowarzyszeniowej Ukrainy z UE oraz wejście w życie DCFTA. Doprowadzito to do stopniowej poprawy bilansu handlowego po 2015 oraz $2016 \mathrm{r}$.

\section{CHARAKTERYSTYKA WSPÓŁPRACY KAPITAŁOWEJ UE-UKRAINA}

Istotnym czynnikiem zarówno wzrostu i rozwoju gospodarczego, jak i podnoszenia konkurencyjności gospodarki są bezpośrednie inwestycje zagraniczne (BIZ). Dla przedsiębiorstw stanowią szansę na rozwój poprzez umiędzynarodowienie. Według Adama Budnikowskiego BIZ to podejmowanie od podstaw samodzielnej działalności

17 V. Jurčák, Bezpieczeństwo Unii Europejskiej w kontekście konfliktu na Ukrainie, „Ante Portas. Studia nad Bezpieczeństwem" 2016, nr 1 (6), s. 15, [online] http://bazhum.muzhp.pl/media//files/Ante_ Portas_Studia_nad_bezpieczenstwem/Ante_Portas_Studia_nad_bezpieczenstwem-r2016-t-n 1_ (6)/Ante_Portas_Studia_nad_bezpieczenstwem-r2016-t-n1_(6)-s13-23/Ante_Portas_Studia_nad_ bezpieczenstwem-r2016-t-n1_(6)-s13-23.pdf, 7 XII 2019.

18 S. Olszyk, Kontekst geopolityczny..., s. 3.

19 Tamże. 
gospodarczej poza granicą kraju, z którego pochodzą środki finansowe, intelektualne czy rzeczowe lub też przejmowanie kierownictwa już istniejącego przedsiębiorstwa, zlokalizowanego poza granicami kraju ${ }^{20}$.

Współpraca kapitałowa pomiędzy UE a Ukrainą ma istotne znaczenie dla intensyfikacji przepływów kapitału w formie BIZ między krajami i osiągania korzyści wynikających z tych przepływów. Niemniej jednak skala i charakter BIZ zależą w głównej mierze od uwarunkowań politycznych, ekonomicznych, prawnych i innych.

Łączna wartość BIZ, które napłynęły na Ukrainę według stanu na 1 stycznia 2010 r., wyniosła 35006,15 mln EUR i była o 8,6\% wyższa niż skumulowana wartość BIZ według stanu na 1 stycznia 2009 r. ${ }^{21} \mathrm{~W} 2010$ r. wartość BIZ na Ukrainie z państw UE stanowiła 18821,74 mln EUR - a więc 53,8\% łącznej wartości BIZ na Ukrainie. Według stanu na 1 stycznia 2011 r. odnotowano chwilowy wzrost wartości BIZ pochodzących z państw UE. Następnie po 2011 r. wartość BIZ z państw UE do 2017 r. stopniowo spadała. Największy spadek odnotowano z 2014 na 2015 r. - wartość BIZ spadła wówczas o 26\%. Po 2017 r. zauważono skromny wzrost wartości BIZ, jednak jego wartość według stanu na 1 stycznia 2018 r. była wciąż niższa w porównaniu z 2010 r. (wykres 2).

Wykres 2. Inwestycje bezpośrednie (kapitał własny) z państw UE na Ukrainę w latach 2010-2018 w mln EUR

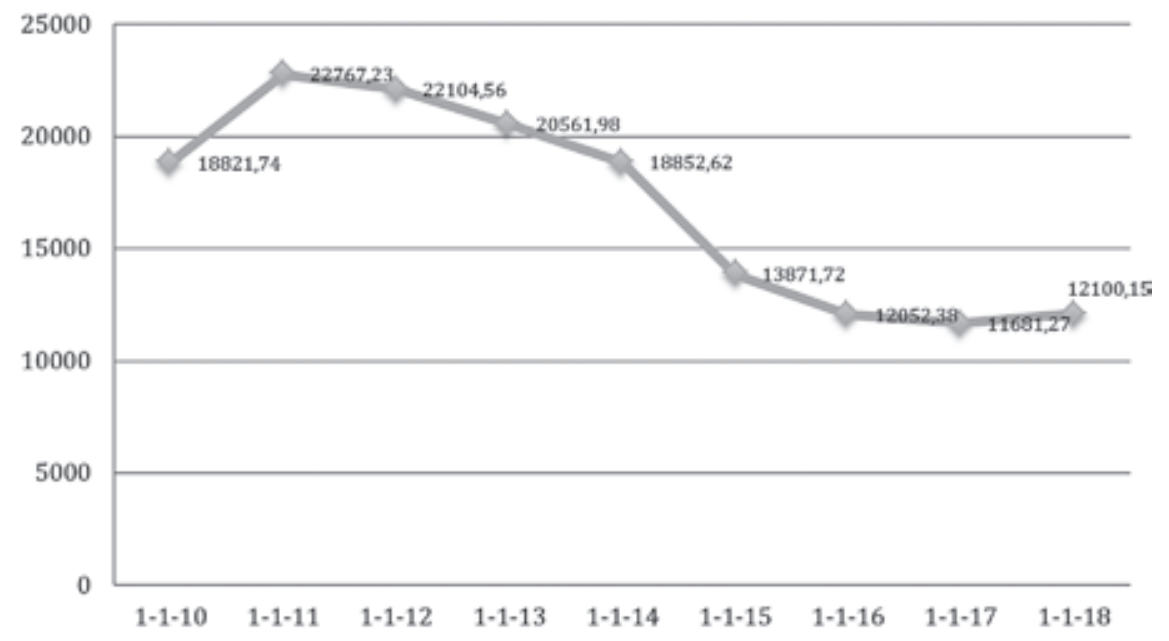

Źródło: Opracowanie własne na podstawie danych Państwowej Służby Statystyki Ukrainy.

20 E. Radomska, Bariery lokowania bezpośrednich inwestycji zagranicznych na Ukrainie - wyzwania i perspektywy inwestycyjnej wspótpracy polsko-ukraińskiej, „Kwartalnik Naukowy Uczelni Vistula” 2016, nr 47 (2), s. 75, [online] https://i.vistula.edu.pl/media/docs/g6hIo7vQafRGThi7R6APjFg1.pdf, 8 XII 2019.

21 Direct investment (equity capital), State Statistics Service of Ukraine, 2018, [online] https://ukrstat. org/en/operativ/operativ2014/zd/pik/pik_e/pik_rik_2014_e.html, 9 XII 2019. 
Łączna wartość BIZ Ukrainy według stanu na 1 stycznia 2010 r. wyniosła 5171,53 mln EUR i była o 7,7\% mniejsza niż skumulowana wartość BIZ według stanu na 1 stycznia 2009 r. ${ }^{22}$ Z Ukrainy do państw UE wpłynęło wówczas 41,1 mln EUR - a więc 0,8\% łącznej wartości BIZ Ukrainy. Według stanu na 1 stycznia 2011 r. odnotowano spadek wartości BIZ, a następnie wzrost. Z 2012 na 2013 r. spostrzeżono największy skok BIZ Ukrainy do państw UE - ich wartość wzrosła o 39\%. Po pewnym czasie ich wartość stabilnie spadała do 2016 r. Po 2016 r. zaobserwowano symboliczny, ale ciągły wzrost (wykres 3).

Wykres 3. Inwestycje bezpośrednie (kapitał własny) z Ukrainy do państw UE w latach 2010-2018 w mln EUR

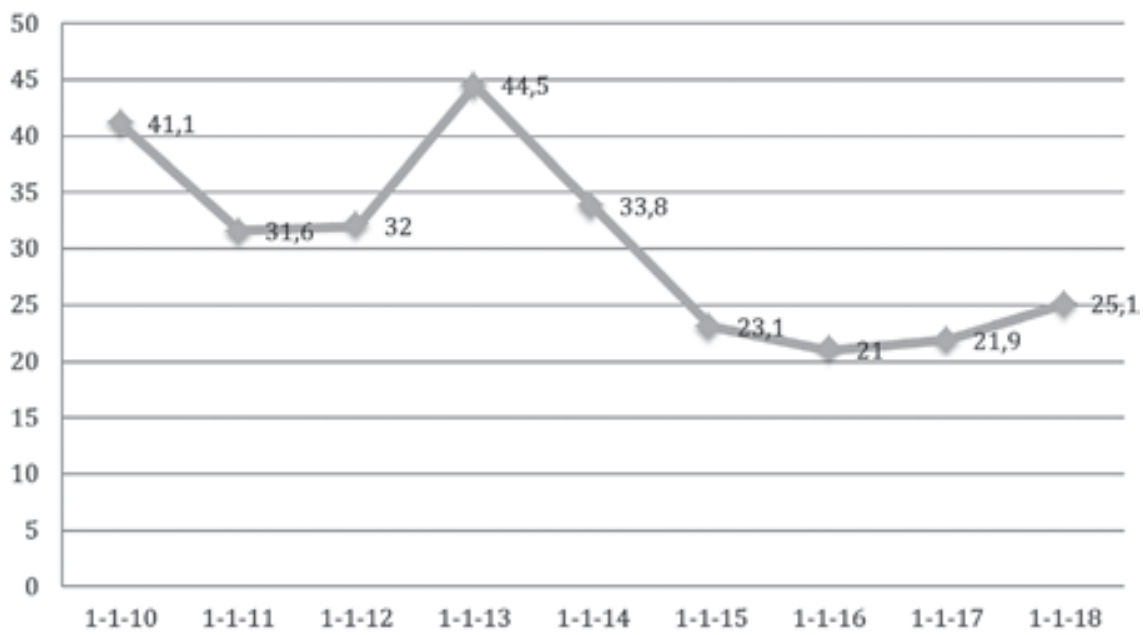

Źródło: Opracowanie własne na podstawie danych Państwowej Służby Statystyki Ukrainy.

Ukraina oceniana jest jako kraj o mało sprzyjającym klimacie inwestycyjnym, odziedziczonym po systemie socjalistycznym, który cechował się wysoką korupcją oraz biurokracją ${ }^{23}$. Według Indeksu Percepcji Korupcji opublikowanego przez Transparency International w 2018 r., na 175 analizowanych państw Ukraina zajęła 120. pozycję̨ Korupcja sprawia, że koszty zawierania transakcji i ryzyko związane z podjęciem inwestycji wzrastają, co zniechęca inwestorów zagranicznych. Z kolei niski poziom korupcji wpływa na BIZ dodatnio. Jednak pomimo walki z korupcją na Ukrainie jej istotnym problemem jest słabość instytucjonalna ${ }^{25}$.

22 Tamże.

23 E. Radomska, Bariery lokowania bezpośrednich inwestycji zagranicznych..., s. 84 .

24 Ukraine Corruption Rank, Trading Economics, 2018, [online] https://tradingeconomics.com/ ukraine/corruption-rank, 10 XII 2019.

25 E. Radomska, Bariery lokowania bezpośrednich inwestycji zagranicznych..., s. 85. 
Otoczenie instytucjonalno-prawne jest istotnym składnikiem klimatu inwestycyjnego kraju goszczącego przepływy kapitałowe w formie BIZ. Niestabilność ukraińskich przepisów prawnych w wielu obszarach utrudnia prowadzenie działalności gospodarczej w tym kraju. Według rankingu Banku Światowego Doing Business w $2019 \mathrm{r}$. Ukraina zajęła 71. miejsce wśród 190 państw ${ }^{26}$, poprawiając swój wcześniejszy wynik. Elementy klimatu inwestycyjnego, takie jak specjalne strefy ekonomiczne czy terytoria priorytetowego rozwoju, odegrały dotychczas znaczącą rolę w aspekcie przyciągania inwestycji zagranicznych na rynek ukraiński.

Do pozostałych barier podejmowania BIZ na rynku ukraińskim zaliczyć można słabość wymiaru sprawiedliwości i trudności w dochodzeniu swoich spraw w sądach, niekorzystne regulacje prawne dotyczące działalności gospodarczej, brak wsparcia inwestorów przez władze lokalne, przeszkody w handlu, wiele ograniczeń pozataryfowych związanych z dopuszczeniem importowanych towarów do rynkowego obrotu, kwestionowanie i podwyższanie wartości celnej importowanych towarów, częste zmiany celnych przepisów, zbyt wolne dostosowywanie się do przepisów unijnych i WTO, zły stan infrastruktury oraz małą liczbę przejść granicznych ${ }^{27}$. Co więcej, problemem są znaczące opóźnienia lub brak zwrotu nadpłaconego podatku VAT. Ustawa o podatku VAT nie zezwala na zerową stawkę podatku VAT na fakturach eksportowych (wynosi ona 20\%). W praktyce urzędy nie zwracają nadpłaconego podatku, argumentując to brakiem środków. Prawo nie zezwala na kompensatę tych środków na poczet przyszłych zobowiązań z tego tytułu, a państwo nie wypłaca zobowiązań mimo orzeczeń i nakazów sądowych. W nielicznych przypadkach zwrot jest dokonywany w wyniku interwencji ambasad ${ }^{28}$.

Do powyższych problemów w znacznym stopniu przyczynił się wybuch kryzysu ukraińskiego. Współpraca kapitałowa pomiędzy UE a Ukrainą zdecydowanie pogorszyła się w 2013 r. - spadła wówczas wartość tak unijnych, jak i ukraińskich BIZ. Sytuacja uległa poprawie dopiero w latach 2016-2017, co objaśnić można wejściem w życie DCFTA.

\section{KONKLUZJE}

Ukraina jest dużym i ważnym sąsiadem oraz partnerem UE, który odniósł już znaczne korzyści w wyniku niedawnego procesu demokratyzacji. Wciąż jednak charakteryzuje się ona mało stabilną sytuacją polityczną oraz szeroką gamą problemów gospodarczych. Kraj zmaga się ze spadkiem aktywności gospodarczej (spadek PKB Ukrainy w 2014 r. wyniósł 6,8\%), wzrostem inflacji (liczony w odniesieniu do analogicznego okresu roku

\footnotetext{
26 Ukraina jest druga pod względem wzrostu w rankingu Doing Business, UkrInform, 28 XII 2019, [online] https://www.ukrinform.pl/rubric-economy/2661863-ukraina-jest-druga-pod-wzgledem-wzrostu-wrankingu-doing-business.html, 28 XII 2019.

27 E. Radomska, Bariery lokowania bezpośrednich inwestycji zagranicznych..., s. 86.

28 Tamże.
} 
poprzedniego wyniósł w październiku 2015 r. aż 46,4\%), spadkiem produkcji przemysłowej i rolnej, spadkiem obrotów handlu zagranicznego (w latach 2013-2015), wycofywaniem wkładów bankowych, z problemami w sferze finansów publicznych oraz szeregiem innych kwestii wynikających z polityki rosyjskiej. Wybuch kryzysu przyczynif się do większości problemów gospodarczych Ukrainy.

Analizując wpływ kryzysu ukraińskiego na integrację gospodarczą Ukrainy z UE, należy jednoznacznie stwierdzić, iż przyczynia się on do niestabilności wymiany handlowej oraz powoduje zakłócenia we współpracy kapitałowej pomiędzy UE a Ukrainą. Główną hipotezą badawczą postawioną w niniejszym artykule jest stwierdzenie, iż kryzys ukraiński spowodował spadek wymiany handlowej oraz pogorszenie się wyników współpracy kapitałowej pomiędzy UE a Ukrainą. Przeprowadzone badania pozwoliły na potwierdzenie postawionej hipotezy.

Wybuch kryzysu ukraińskiego poskutkował spadkiem wartości eksportu, importu oraz BIZ pomiędzy UE a Ukrainą po 2013 r. Eskalacja kryzysu z roku na rok doprowadzała do coraz gorszych wyników, natomiast po wejściu w życie DCFTA współpraca ta uległa poprawie. Warto jednak zaznaczyć, że wyniki ostatnich lat nie zaskakują. W 2018 r. wartość zarówno unijnych, jak i ukraińskich BIZ była niższa niż w 2010 r. Bilans handlowy w 2018 r. również nie wykazał najlepszych wyników.

Mimo istnienia wysokiego poziomu ryzyka związanego z prowadzeniem działalności gospodarczej i mało przyjaznego klimatu inwestycyjnego, Ukraina jest atrakcyjnym miejscem lokowania BIZ. Angażując kapitał w formie BIZ na Ukrainie, inwestorzy zagraniczni spodziewają się uzyskiwać korzyści wielokrotnie przewyższające istniejące ryzyko.

\section{BIBLIOGRAFIA}

1 stycznia wchodzi w życie DCFTA - umowa o wolnym handlu z Ukraina, Polska Agencja Prasowa, 1 I 2016, [online] https://www.pap.pl/aktualnosci/news\%2C452052\%2C1-stycznia-wchodzi-w-zycie-dcfta---umowa-o-wolnym-handlu-z-ukraina.html.

Direct investment (equity capital), State Statistics Service of Ukraine, 2018, [online] https:// ukrstat.org/en/operativ/operativ2014/zd/pik/pik_e/pik_rik_2014_e.html.

Dierżawna służba statistiki Ukraïni, [online] http://www.ukrstat.gov.ua.

Jurčák V., Bezpieczeństwo Unii Europejskiej w kontekście konfliktu na Ukrainie, „Ante Portas. Studia nad Bezpieczeństwem" 2016, nr 1 (6), [online] http://bazhum.muzhp.pl/media//files/ Ante_Portas_Studia_nad_bezpieczenstwem/Ante_Portas_Studia_nad_bezpieczenstwemr2016-t-n1_(6)/Ante_Portas_Studia_nad_bezpieczenstwem-r2016-t-n1_(6)-s13-23/ Ante_Portas_Studia_nad_bezpieczenstwem-r2016-t-n1_(6)-s13-23.pdf.

Labuda M., Realizacja Partnerstwa Wschodniego przez Ukraine, „Kurier Galicyjski” 2018, nr 13 (305).

Luczkiewicz H., Czy umowy handlowe zawierane przez UE przynosza realne korzyści?, 21 III 2019, [online] https://www.wnp.pl/rynki-zagraniczne/czy-umowy-handlowe-zawierane-przez-ue-przynosza-realne-korzysci,342256.html. 
Olszyk S., Kontekst geopolityczny kryzysu na Ukrainie (2013-2014) i zaangażowanie wtadz polskich w jego rozwiązanie, „Środkowoeuropejskie Studia Polityczne” 2016, nr 3, https://doi. org/10.14746/ssp.2016.3.12.

Płonka B., Umowa UE-Ukraina o utworzeniu pogtębionej i kompleksowej strefy wolnego handlu (DCFTA) jako przyktad nowej generacji porozumień preferencyjnych, „Zeszyt Naukowy Wyższej Szkoły Zarządzania i Bankowości w Krakowie” 2015, nr 38, [online] http:// cejsh.icm.edu.pl/cejsh/element/bwmeta1.element.desklight-37e7a265-a232-42ea-8537-f87f912d8190/c/plonka.pdf.

Radomska E., Bariery lokowania bezpośrednich inwestycji zagranicznych na Ukrainie - wyzwania i perspektywy inwestycyjnej wspótpracy polsko-ukraińskiej, „Kwartalnik Naukowy Uczelni Vistula” 2016, nr 47 (2), [online] https://i.vistula.edu.pl/media/docs/g6hIo7vQafRGThi7R6APjFg1.pdf.

Radomska E., DCFTA - umowa o strefie wolnego handlu Ukrainy z Unia Europejska - szanse, zagrożenia, wyzwanie, „Kwartalnik Naukowy Uczelni Vistula” 2017, nr 2 (55), [online] http://cejsh.icm.edu.pl/cejsh/element/bwmeta1.element.desklight-ad85d97f-88e3-4dee9bf6-a6778beda041/c/04_PDFsam_KNUV_52_poprawiony.pdf.

Truszczyński J., Partnerstwo Wschodnie - geneza i wstępny bilans, [w:] Partnerstwo Wschodnie Unii Europejskiej, red. M. Grela, Z. Rapacki, Warszawa 2016.

Układ o stowarzyszeniu między Unią Europejską i jej państwami członkowskimi, z jednej strony, a Ukrainą, z drugiej strony, Dz. U. UE, L 161/3.

Ukraina bierze się za handel z Unia. Wżycie wchodzi DCFTA, TVN 24 BIS, 1 I 2016, [online] https://tvn24bis.pl/ze-swiata,75/1-stycznia-wchodzi-w-zycie-dcfta-umowa-o-wolnymhandlu-z-ukraina,607341.html.

Ukraina jest druga pod względem wzrostu w rankingu Doing Business, UkrInform, 28 XII 2019, [online] https://www.ukrinform.pl/rubric-economy/2661863-ukraina-jest-druga-podwzgledem-wzrostu-w-rankingu-doing-business.html.

Ukraine Corruption Rank, Trading Economics, 2018, [online] https://tradingeconomics.com/ ukraine/corruption-rank.

Unia Europejska i jej partnerzy handlowi, Parlament Europejski. Noty tematyczne o Unii Europejskiej, 1 XI 2019, [online] http://www.europarl.europa.eu/ftu/pdf/pl/FTU_5.2.1.pdf.

Marta LABUDA - doktorantka w Katedrze Studiów nad Procesami Integracyjnymi w Instytucie Nauk Politycznych i Stosunków Międzynarodowych Uniwersytetu Jagiellońskiego. Absolwentka studiów magisterskich na kierunku stosunki międzynarodowe oraz zarządzanie - finanse i controlling na UJ. Stypendystka rządu RP w latach 2013-2018. W pracy naukowej podejmuje tematykę związaną z integracją europejską, w szczególności europejską polityką sąsiedztwa, wspólną polityką handlową oraz prawem gospodarczym Unii Europejskiej. Do jej zainteresowań należą również szeroko pojęte etyczne problemy polityki. 